\title{
Combinations of Ethephon and Accel for Thinning 'Delicious' Apple Trees
}

\author{
Richard P. Marini \\ Department of Horticulture, Virginia Polytechnic Institute and State University, Blacksburg, VA 24061
}

AdDitional INDEX wORDs. Malus xsylvestris var. domestica, abscission, PGR, fruit set, fruit weight

\begin{abstract}
For 4 years, 'Redchief Delicious' apple [Malus xsylvestris (L.) Mill. var. domestica (Borkh.) Mansf.] trees were treated with ethephon and/or Accel (6-BA + Gibberellins $\left.{ }_{4+7}\right)$ when average fruit diameter was 5.0 to 11.4 mm. Effective thinning was obtained with ethephon at concentrations $>500 \mathrm{mg} \cdot \mathrm{L}^{-1}$ and with Accel at concentrations of 100 to $125 \mathrm{mg} \cdot \mathrm{L}^{-1}$. In only 1 year out of $\mathbf{4}$ did combinations of Accel plus ethephon reduce fruit set more than either material applied alone. Repeat applications of either material alone or in combination reduced fruit set no more than single applications. Fruit weight was negatively related to the number of fruit per tree. After adjusting fruit weight for number of fruit per tree at harvest with analysis of covariance, ethephon did not improve fruit weight at harvest, but Accel improved fruit weight in two of three experiments. The effect of combinations of Accel and ethephon on fruit weight was inconsistent. Chemical names used: 2-chloroethyl phosphonic acid (ethephon); polyothyethylleneploypropanol dihydroxy-propane 2, butoxyethanol (Regulaid); N-(phenylmethyl)-1H-purine-6-amine plus giberrellins $\mathrm{A}_{\mathrm{A}+\mathrm{A} 7}$ (Accel).
\end{abstract}

Apple [Malus xsylvestris (L.) Mill. var. domestica (Borkh.) Mansf.] trees are chemically thinned to enhance average fruit size, fruit quality, and bloom the following season. Spur 'Delicious' trees are difficult to adequately thin in Virginia. Carbamate insecticides usually provide moderate, but inadequate, levels of thinning (Byers, 1978). Naphthaleneacetic acid (NAA), alone or combined with carbamates, usually results in too little thinning (Marini, 2002). Ethephon can be an effective thinner, but because results may depend on concentration of active ingredient (Jones et al., 1983; Koen and Jones, 1985; Marini, 1996), temperature (Jones and Koen, 1985; Marini, 2001a) and the amount of water applied per hectare (Jones et al., 1991), commercial producers are concerned about inconsistent results. Accel became available for chemical thinning in 1994 and contains benzyladenine (BA) and gibberellins $(\mathrm{GA})_{4+7}$. Accel often removes fewer fruit than carbaryl, but the combination of the two materials is more effective than either alone (Greene and Autio, 1995). Combinations of carbamates and ethephon provide more thinning than either material alone, and sometimes result in overthinning (Marini, 1996). Therefore carbamates are the usual choice for thinning 'Delicious', but follow-up hand-thinning is often required to adequately adjust the crop load.

Carbamates do not fit well into the Virginia Integrated Pest Management Program because they are toxic to mite predators. Additionally, carbamates will soon be reviewed by the Environmental Protection Agency and their registration as thinners may be modified. For these reasons, development of a chemical thinning program that does not include carbamates would be desirable. The purpose of this study was to evaluate ethephon and Accel, alone or in combination, as chemical thinners for spur-type 'Delicious' trees.

\section{Materials and Methods}

GeNERAL. Four experiments were performed using trees growing at the Virginia Tech College of Agriculture and Life Sciences Kentland Farm, near Blacksburg, Va. (lat. 37.22 $88^{\prime} 04^{\prime} \mathrm{N}$, long. $\left.80.42^{\circ} 73^{\prime} 13^{\prime} \mathrm{E}\right)$. Trees used in 1999 and 2001 were 'Campbell Redchief Delicious' on M.26 EMLA rootstock, planted in 1988

Received for publication 7 July 2003. Accepted for publication 23 Oct. 2003. at a spacing of $3.0 \times 6.4 \mathrm{~m}$. Trees used in 2000 and 2002 were 'Mercier Redchief Delicious' on M.26 EMLA planted in 1989 at a spacing of $3.0 \times 6.4 \mathrm{~m}$. Tree canopies were $\approx 3.3 \mathrm{~m}$ in diameter and $\approx 3.9 \mathrm{~m}$ tall, and tree-row-volume was $\approx 50 \%$ (Byers, 1987). Trees were supported with conduit fastened to a single wire at 2.1 $m$ above ground and trees were trained as central leaders (Marini, 2001b). A 2-m wide herbicide strip was maintained under the trees, and trees were not irrigated. Pest control was according to local recommendations. Details concerning average fruit diameter, temperatures, and solar radiation at treatment time are presented in Table 1 . The year after treatment each tree was visually rated for return bloom on a scale of 1 to 7 , where $1=$ no bloom, $3=$ moderate bloom, and $7=$ very heavy bloom.

COMBINATIONS OF SURFACTANTS, ETHEPHON, AND ACCEL, 1999. On 26 Apr. 1999, when trees were in full bloom, 54 trees with heavy bloom were selected and three trees were assigned randomly to each of 18 treatment combinations. The experiment was a $2 \times 3 \times 3$ factorial in a completely randomized design (CRD), with three single-tree-replicates. The treatment factors included two surfactants (Regulaid; Kalo Inc., Overland Park, Kans. at $1.25 \mathrm{~mL} \cdot \mathrm{L}^{-1}$ vs. 70-s superior oil; Sun Spray 6E, Sun Co., Inc., Philadelphia, $\mathrm{Pa}$. at $5.0 \mathrm{~mL} \cdot \mathrm{L}^{-1}$ ), three concentrations of Accel (Valent USA Corp., Walnut Creek, Calif.) at 0,25 or $50 \mathrm{mg} \cdot \mathrm{L}^{-1}$, and three concentrations of ethephon (Ethrel, Aventis Crop Science, Research Triangle Park, N.C.) at 0,200 , or $400 \mathrm{mg} \cdot \mathrm{L}^{-1}$. On 10 May, when fruit diameter averaged $9.2 \mathrm{~mm}$, trees were sprayed to runoff with a hand-held sprayer with an average of $5.3 \mathrm{~L}$ of solution per tree $\left(2760 \mathrm{~L} \cdot \mathrm{ha}^{-1}\right)$. The day before treatment, three limbs per tree, with 100 to 130 blossom clusters, were tagged and the number of blossom clusters was recorded. Six weeks after treatment the number of fruit per limb was recorded and fruit set per 100 blossom clusters was calculated. Analysis of variance was performed with SAS's GLM Procedure (SAS Inst. 1992) and sums of squares associated with the main effects and the interactions were partitioned with single-degree-of-freedom contrasts.

TIME OF ETHEPHON AND ACCEL APPLICATION. On 19 Apr. 2000, when trees were in full bloom, 36 trees with heavy bloom were selected and three trees were assigned randomly to each of 12 treatment combinations. The experiment was an augmented factorial (Lentner and Bishop, 1993) in a CRD. A factorial arrangement of four treatments involving two levels of Accel $\left(0 \mathrm{vs} .100 \mathrm{mg} \cdot \mathrm{L}^{-1}\right)$ 
and two levels of ethephon ( $\left.0 \mathrm{vs} .500 \mathrm{mg} \cdot \mathrm{L}^{-1}\right)$ were applied on 1 , 8 , or 1 May plus 8 May, and 70-s superior oil, at the rate of $7.5 \mathrm{~mL} \cdot \mathrm{L}^{-1}$, was added to all treatments. Fruit diameter averaged $5.5 \mathrm{~mm}(0.39 \mathrm{~g})$ on 1 May and $8.9 \mathrm{~mm}(0.62 \mathrm{~g})$ on 8 May. Trees were sprayed to runoff with a hand-held sprayer with an average of $4.4 \mathrm{~L}$ of solution per tree $\left(2200 \mathrm{~L} \cdot \mathrm{ha}^{-1}\right)$. Fruit set per 100 blossom clusters was calculated as previously described. On 20 Sept. all trees were harvested and yield ( $\mathrm{kg} / \mathrm{tree})$ and the number of fruit per tree were recorded. Crop density was calculated as number of fruit $/ \mathrm{cm}^{2}$ of trunk cross-sectional area (TCA), and yield efficiency was calculated as $\mathrm{kg}$ of fruit $/ \mathrm{cm}^{2} \mathrm{TCA}$. Analysis of variance was performed on each response variable and the sums of squares due to the main effects and interactions were partitioned with single degree-of-freedom contrasts similar to those described by Marini (2003).

ETHEPHON WITH VARYING CONCENTRATIONS OF ACCEL, 2001. On 24 Apr., when trees were in full bloom, 30 trees with heavy bloom were selected and three trees were assigned randomly to each of 10 treatment combinations. The experiment was a $2 \times 5$ factorial in a CRD, with two levels of ethephon $\left(0 \mathrm{vs} .300 \mathrm{mg} \cdot \mathrm{L}^{-1}\right)$ and five levels of Accel $\left(0,50,100,150\right.$, and $\left.200 \mathrm{mg} \cdot \mathrm{L}^{-1}\right)$. All treatments included 70 -s superior oil at the rate of $7.5 \mathrm{~mL} \cdot \mathrm{L}^{-1}$. All treatments were applied on 7 May, when fruit diameter averaged $11.4 \mathrm{~mm}$ $(1.23 \mathrm{~g})$. Trees were sprayed to runoff with a hand-held sprayer with an average of $3.9 \mathrm{~L}$ of solution per tree $\left(2035 \mathrm{~L} \cdot \mathrm{ha}^{-1}\right)$. Fruit set per 100 blossom clusters was calculated as previously described. On 15 Sept. all trees were harvested and yield ( $\mathrm{kg} /$ tree) and the number of fruit per tree were recorded, and crop density and yield efficiency were calculated. Fruit were segregated into seven sizes with a weight sizer and crop value was calculated for each tree using prices reported for Appalachian fruit during October. Analysis of variance was performed on each response variable and the sums of squares due to the main effects and interactions were partitioned with single degree-of-freedom contrasts.

ACCEL With VARYing CONCENTRATIONS OF ETHEPHON, 2002. On 17 Apr., when trees were in full bloom, 30 trees with heavy bloom were selected and three trees were assigned randomly to each of 10 treatment combinations. The experiment was a $2 \times 5$ factorial in a CRD, with two levels of Accel (0 vs. $\left.150 \mathrm{mg} \cdot \mathrm{L}^{-1}\right)$ and five levels of ethephon $\left(0,150,300,450\right.$, and $\left.600 \mathrm{mg} \cdot \mathrm{L}^{-1}\right)$. All treatments included 70 -s superior oil at the rate of $7.5 \mathrm{~mL} \cdot \mathrm{L}^{-1}$. All treatments were applied on 30 Apr., when the stage of bloom was petal fall and fruit diameter averaged $5.0 \mathrm{~mm}(0.23 \mathrm{~g})$. Trees were sprayed to runoff with a hand-held sprayer with an average of $5.1 \mathrm{~L}$ of solution per tree $\left(2660 \mathrm{~L} \cdot \mathrm{ha}^{-1}\right)$. Fruit set per 100 blossom clusters were calculated as previously described. On 15 Sept. all trees were harvested and yield and the number of fruit per tree were recorded, and crop density and yield efficiency were calculated. Crop value was calculated as previously described. Analysis of variance was performed on each response variable and the sums of squares due to the main effects and interactions were partitioned with single degree-of-freedom contrasts.

\section{Results}

1999. There was little evidence that fruit set was influenced by the main effects, and the only interaction that was significant was the surfactant $\times$ Accel $_{\text {quadratic }}$ interaction (Table 2). Pooled over all ethephon treatments, there was no relationship between Accel concentration and fruit set when oil was added to the spray solution. However, when Regulaid was added to the solution, fruit set was negatively related to Accel concentration in a curvilinear manner and fruit set was lowest with $25 \mathrm{mg} \cdot \mathrm{L}^{-1}$. Fruit set was excessive for all trees, so trees were defruited by hand in July to prevent limb breakage. The three-way interaction was significant for return bloom. When oil was added to the solution, return bloom was very poor. When Regulaid was used, return bloom was greatest for trees treated with the highest rate of ethephon, but these results must be interpreted cautiously because bloom for all treatments was inadequate for even a moderate crop.

2000. For most variables the main effects and the three-way interaction were significant, therefore the data were evaluated by partitioning the sums of squares for each main effect into two orthogonal contrasts (Table 3). Fruit set was reduced by the main effects of Accel and by ethephon. Fruit set was reduced to a greater extent by treatment on 8 May than on 1 May, but repeat applications were not different than the average of the two single applications. The combination of the two materials did not reduce fruit set more than when the materials were applied separately. When either Accel or ethephon were applied alone, fruit harvested per tree, yield, crop density (CD) and yield efficiency were reduced compared to the control, but the response was similar for the two application dates. Repeat application of Accel reduced all four response variables more than the average of the two dates (Table 3). All four response variables were reduced more by the combination of the two materials than by application of either material alone. For the combination treatment, the responses were similar for the two application dates, and the responses were no greater when the combination was applied twice compared to the average of the two single applications. Fruit weight was increased by both Accel and ethephon (Table 3). The response was greatest when the two materials were combined, but two applications were no more effective than a single application. Fruit weight appeared to be related to the crop load. For these trees, the ideal CD was 4.0 to 5.0 fruit $/ \mathrm{cm}^{2}$ TCSA, which was obtained with a single application of Accel and trees were overthinned by treatments containing ethephon. The return bloom rating in 2001 was linearly related to the covariate, number of fruit harvested per tree in 2000. After adjusting the means for the covariate, the three-way interaction was not significant for return bloom in 2001 (Table 3).

Table 1. Average fruit diameter on the day of treatment, maximum temperatures and solar radiation for the day of treatment and the $3 \mathrm{~d}$ following treatment for the four experiments in this study.

\begin{tabular}{|c|c|c|c|c|c|c|c|c|c|}
\hline \multirow{2}{*}{$\begin{array}{l}\text { Treatment } \\
\text { date }\end{array}$} & \multirow{2}{*}{$\begin{array}{l}\text { Avg fruit } \\
\text { diam } \\
(\mathrm{mm})\end{array}$} & \multicolumn{4}{|c|}{$\begin{array}{l}\text { Max temp }\left({ }^{\circ} \mathrm{C}\right) \text { on the following } \\
\text { days after treatment }\end{array}$} & \multicolumn{4}{|c|}{$\begin{array}{l}\text { Daily solar radiation }\left(\mathrm{kW} \cdot \mathrm{m}^{-2}\right) \text { on the } \\
\text { following days after treatment }\end{array}$} \\
\hline & & 0 & 1 & 2 & 3 & 0 & 1 & 2 & 3 \\
\hline 10 May 1999 & 9.2 & 25.7 & 25.4 & 26.1 & 22.4 & 7.622 & 7.522 & 7.492 & 3.722 \\
\hline 1 May 2000 & 5.5 & 24.1 & 21.5 & 23.9 & 24.9 & 6.921 & 4.124 & 6.754 & 5.547 \\
\hline 8 May 2000 & 8.9 & 26.7 & 28.0 & 25.5 & 27.1 & 6.069 & 6.366 & 6.553 & 5.316 \\
\hline 7 May 2001 & 11.4 & 19.1 & 16.6 & 23.0 & 24.8 & 6.886 & 6.895 & 6.541 & 5.038 \\
\hline 30 Apr. 2002 & 5.0 & 22.1 & 24.7 & 26.2 & 16.2 & 7.303 & 4.276 & 3.217 & 4.687 \\
\hline
\end{tabular}


Accel alone did not improve return bloom, but ethephon improved return bloom to a similar extent regardless of application date and wether or not it was combined with Accel.

It is difficult to determine if treatments influenced fruit weight directly because fruit weight appeared to be related to crop load. Therefore analysis of covariance was performed to account for the differences in crop load, where the number of fruit per tree was included in the model as a covariate and ethephon and Accel were included as qualitative variables. The approach, using SAS's Mixed Procedure described by Marini et al. (2002) was used for determining the form of the covariate part of the model. The three-way interaction (covariate $\times$ Accel $\times$ ethephon) was significant, indicating that the relationship between crop load and fruit weight was not the same for all treatments. Therefore least squares means were estimated for three levels of crop load and least squares means within each crop load level were compared with the probability of the difference (PDIFF), which is the least significant difference adjusted for the covariate. For trees with a light crop (250 fruit per tree), fruit weight was highest on trees treated with a combination of Accel plus ethephon and lowest for trees treated with Accel (Table 4). Treatment least squares means for trees with moderate (400 fruit/tree) and high (550 fruit/tree) crop loads did not differ significantly $(P=0.05)$.

2001. Fruit set was not affected by the main effect of ethephon
(Table 5). Fruit set was related to Accel concentration in a quadratic manner. Fruit set was reduced $10 \%$ to $30 \%$ with Accel concentrations of 50 to $150 \mathrm{mg} \cdot \mathrm{L}^{-1}$, but with $200 \mathrm{mg} \cdot \mathrm{L}^{-1}$ fruit set was greater than for the control trees. The number of fruit harvested per tree and yield were reduced by ethephon, but not by Accel. Fruit weight was negatively related to Accel concentration, but when combined with ethephon fruit weight was positively related to Accel concentration. Crop density and yield efficiency were significantly affected by the ethephon $\times$ Accel $_{\text {Quadratic }}$ interaction. Without ethephon, Accel thinned most effectively at $100 \mathrm{mg} \cdot \mathrm{L}^{-1}$, but when combined with ethephon, Accel was most effective at $200 \mathrm{mg} \cdot \mathrm{L}^{-1}$. The percentage of small fruit increased linearly with increasing concentration of Accel, but when Accel was combined with ethephon the percentage of small fruit was inconsistently affected. The crop value was reduced by ethephon, but not by Accel. For most trees, bloom in 2002 was adequate for a full crop, but when analysis of covariance was used to adjust bloom ratings for the number of fruit harvested per tree in 2001, bloom rating was not influenced by any of the treatments (Table 5).

Analysis of covariance was performed to determine the effects of Accel and ethephon independent of crop load. The interaction of crop load $\times$ Accel $\times$ ethephon was not significant, but fruit/tree was significant $(P=0.018)$, indicating that the relationship between fruit weight and crop load was not affected by ethephon

Table 2. Fruit set (fruit/100 blossom clusters) in 1999 and return bloom in 2000 for 'Campbell Redchief Delicious' trees sprayed with combinations of surfactants, ethephon and Accel in 1999.

\begin{tabular}{|c|c|c|c|c|c|}
\hline \multirow[b]{2}{*}{$\begin{array}{l}\text { Ethephon } \\
\left(\mathrm{mg} \cdot \mathrm{L}^{-1}\right)\end{array}$} & \multirow[b]{2}{*}{$\begin{array}{c}\text { Accel } \\
\left(\mathrm{mg} \cdot \mathrm{L}^{-1}\right)\end{array}$} & \multicolumn{2}{|c|}{ Fruit/100 clusters } & \multicolumn{2}{|c|}{ Bloom ratingz } \\
\hline & & $\begin{array}{c}\text { Oil } \\
\left(5.0 \mathrm{~mL} \cdot \mathrm{L}^{-1}\right)\end{array}$ & $\begin{array}{c}\text { Regulaid } \\
\left(1.25 \mathrm{~mL} \cdot \mathrm{L}^{-1}\right)\end{array}$ & $\begin{array}{c}\text { Oil } \\
\left(5.0 \mathrm{~mL} \cdot \mathrm{L}^{-1}\right)\end{array}$ & $\begin{array}{c}\text { Regulaid } \\
\left(1.25 \mathrm{~mL} \cdot \mathrm{L}^{-1}\right)\end{array}$ \\
\hline \multirow[t]{3}{*}{0} & 0 & 117 & 141 & 1.0 & 1.0 \\
\hline & 25 & 113 & 102 & 1.5 & 1.0 \\
\hline & 50 & 83 & 106 & 1.0 & 1.0 \\
\hline \multirow[t]{3}{*}{200} & 0 & 134 & 102 & 1.0 & 1.0 \\
\hline & 25 & 123 & 82 & 1.0 & 1.0 \\
\hline & 50 & 112 & 115 & 1.3 & 1.3 \\
\hline \multirow[t]{3}{*}{400} & 0 & 96 & 125 & 1.3 & 1.7 \\
\hline & 25 & 108 & 61 & 1.0 & 1.8 \\
\hline & 50 & 141 & 95 & 1.0 & 1.3 \\
\hline \multicolumn{6}{|l|}{$P$ values } \\
\hline Surfactant (S) & & \multicolumn{2}{|c|}{0.146} & \multicolumn{2}{|c|}{0.075} \\
\hline Ethephon (E) & & \multicolumn{2}{|c|}{0.693} & \multicolumn{2}{|c|}{0.013} \\
\hline $\mathrm{E}_{\mathrm{L}}^{\mathrm{y}}$ & & \multicolumn{2}{|c|}{0.507} & \multicolumn{2}{|c|}{0.011} \\
\hline $\mathrm{E}_{\mathrm{Q}}$ & & \multicolumn{2}{|c|}{0.617} & \multicolumn{2}{|c|}{0.177} \\
\hline $\operatorname{Accel}(\mathrm{A})$ & & \multicolumn{2}{|c|}{0.082} & \multicolumn{2}{|c|}{0.128} \\
\hline $\mathrm{A}_{\mathrm{L}}$ & & \multicolumn{2}{|c|}{0.248} & \multicolumn{2}{|c|}{1.000} \\
\hline $\mathrm{A}_{\mathrm{Q}}$ & & \multicolumn{2}{|c|}{0.058} & \multicolumn{2}{|c|}{0.045} \\
\hline $\mathrm{S} \times \mathrm{E}$ & & \multicolumn{2}{|c|}{0.104} & \multicolumn{2}{|c|}{0.009} \\
\hline $\mathrm{S} \times \mathrm{E}_{\mathrm{L}}$ & & \multicolumn{2}{|c|}{0.062} & \multicolumn{2}{|c|}{0.007} \\
\hline $\mathrm{S} \times \mathrm{E}_{\mathrm{Q}}$ & & \multicolumn{2}{|c|}{0.257} & \multicolumn{2}{|c|}{0.213} \\
\hline $\mathrm{S} \times \mathrm{A}$ & & \multicolumn{2}{|c|}{0.094} & \multicolumn{2}{|c|}{0.187} \\
\hline $\mathrm{S} \times \mathrm{A}_{\mathrm{L}}$ & & \multicolumn{2}{|c|}{0.448} & & \\
\hline $\mathrm{S} \times \mathrm{A}_{\mathrm{Q}}$ & & & & & \\
\hline $\mathrm{E} \times \mathrm{A}$ & & & & & \\
\hline $\mathrm{E}_{\mathrm{L}} \times \mathrm{A}_{\mathrm{L}}$ & & & & & \\
\hline $\mathrm{E}_{\mathrm{L}} \times \mathrm{A}_{\mathrm{Q}}$ & & & & & \\
\hline $\mathrm{E}_{\mathrm{Q}} \times \mathrm{A}_{\mathrm{L}}$ & & & & & \\
\hline $\mathrm{E}_{\mathrm{Q}} \times \mathrm{A}_{\mathrm{Q}}$ & & & & & \\
\hline $\mathrm{S} \times \mathrm{E} \times \mathrm{A}$ & & & & & \\
\hline
\end{tabular}

${ }^{2}$ Return bloom was rated on a scale from 1 to 7 , where 1 = very light, $4=$ moderate, and $7=$ very heavy.

$\mathrm{y} \mathrm{L}=$ linear and $\mathrm{Q}=$ quadratic effects. 
Table 3. Fruit set (fruit/100 blossom clusters), yield, average fruit weight, crop yield density, efficiency, and return bloom in 2001 as influenced by spraying 'Mercier Redchief Delicious' trees with combinations of Accel and ethephon on different dates in 2000.

\begin{tabular}{|c|c|c|c|c|c|c|c|c|c|}
\hline $\begin{array}{l}\text { Treatment } \\
\text { date }\end{array}$ & $\begin{array}{c}\text { Accel } \\
\left(\mathrm{mg} \cdot \mathrm{L}^{-1}\right)\end{array}$ & $\begin{array}{l}\text { Ethephon } \\
\left(\mathrm{mg} \cdot \mathrm{L}^{-1}\right)\end{array}$ & $\begin{array}{c}\text { Fruit } \\
\text { set }\end{array}$ & $\begin{array}{l}\text { Fruit/ } \\
\text { tree }\end{array}$ & $\begin{array}{c}\text { Fruit } \\
\text { Yield } \\
\text { (kg/tree) }\end{array}$ & $\begin{array}{c}\text { Crop } \\
\text { wt } \\
(\mathrm{g})\end{array}$ & $\begin{array}{c}\text { Yield } \\
\text { density } \\
\left(\text { fruit } / \mathrm{cm}^{2}\right)\end{array}$ & $\begin{array}{l}\text { efficiency } \\
\left(\mathrm{kg} \cdot \mathrm{cm}^{-2}\right)\end{array}$ & $\begin{array}{l}\text { Bloom } \\
\text { ratingz }\end{array}$ \\
\hline \multirow[t]{4}{*}{1 May } & 0 & 0 & 62 & 927 & 125.5 & 147 & 8.9 & 1.19 & 2.5 \\
\hline & 0 & 500 & 50 & 343 & 52.4 & 185 & 3.2 & 0.49 & 6.1 \\
\hline & 100 & 0 & 64 & 485 & 80.6 & 190 & 4.6 & 0.79 & 4.2 \\
\hline & 100 & 500 & 50 & 192 & 34.3 & 233 & 1.7 & 0.30 & 6.3 \\
\hline \multirow[t]{4}{*}{8 May } & 0 & 0 & 112 & 722 & 99.1 & 155 & 6.8 & 0.93 & 2.2 \\
\hline & 0 & 500 & 34 & 326 & 57.9 & 206 & 2.9 & 0.52 & 7.0 \\
\hline & 100 & 0 & 46 & 628 & 93.2 & 165 & 4.9 & 0.72 & 2.9 \\
\hline & 100 & 500 & 40 & 136 & 27.2 & 252 & 1.1 & 0.23 & 5.8 \\
\hline \multirow[t]{4}{*}{1 and 8 May } & 0 & 0 & 65 & 766 & 108.7 & 156 & 6.9 & 0.97 & 2.0 \\
\hline & 0 & 500 & 54 & 213 & 33.3 & 178 & 2.0 & 0.31 & 6.4 \\
\hline & 100 & 0 & 35 & 202 & 30.1 & 169 & 1.7 & 0.25 & 2.0 \\
\hline & 100 & 500 & 56 & 152 & 28.7 & 220 & 1.7 & 0.32 & 6.9 \\
\hline \multicolumn{10}{|l|}{$P$ values } \\
\hline Date (D) & & & 0.169 & 0.010 & 0.009 & 0.163 & 0.003 & 0.001 & 0.424 \\
\hline 1 May vs. 8 May & & & 0.844 & 0.484 & 0.581 & 0.421 & 0.105 & 0.118 & 0.375 \\
\hline$(1$ May +8 May $)$ vs. $1 \& 8$ May & & & 0.063 & 0.003 & 0.003 & 0.084 & 0.002 & 0.001 & 0.304 \\
\hline $\operatorname{Accel}(\mathrm{A})$ & & & 0.001 & 0.001 & 0.001 & 0.001 & 0.001 & 0.001 & 0.426 \\
\hline 1 May vs. 8 May y & & & 0.002 & 0.001 & 0.202 & 0.001 & 0.556 & 0.401 & 0.385 \\
\hline$(1$ May +8 May $)$ vs. $1 \& 8$ May $^{x}$ & & & 0.635 & 0.043 & 0.002 & 0.451 & 0.001 & 0.002 & 0.836 \\
\hline Ethephon $(\mathrm{E})$ & & & 0.001 & 0.001 & 0.001 & 0.001 & 0.001 & 0.001 & 0.001 \\
\hline 1 May vs. 8 May & & & 0.021 & 0.955 & 0.702 & 0.052 & 0.496 & 0.236 & 0.106 \\
\hline$(1$ May + 8 May $)$ vs. $1 \& 8$ May & & & 0.159 & 0.104 & 0.166 & 0.155 & 0.025 & 0.024 & 0.069 \\
\hline$A+E$ & & & 0.018 & 0.001 & 0.001 & 0.001 & 0.001 & 0.001 & 0.001 \\
\hline 1 May vs. 8 May & & & 0.011 & 0.569 & 0.639 & 0.195 & 0.497 & 0.503 & 0.606 \\
\hline$(1$ May +8 May $)$ vs. $1 \& 8$ May & & & 0.061 & 0.884 & 0.843 & 0.042 & 0.600 & 0.515 & 0.080 \\
\hline $\mathrm{D} \times \mathrm{A}$ & & & 0.651 & 0.168 & 0.292 & 0.340 & 0.362 & 0.580 & 0.158 \\
\hline $\mathrm{D} \times \mathrm{E}$ & & & 0.029 & 0.260 & 0.351 & 0.059 & 0.064 & 0.041 & 0.029 \\
\hline $\mathrm{A} \times \mathrm{E}$ & & & 0.003 & 0.007 & 0.046 & 0.060 & 0.001 & 0.002 & 0.001 \\
\hline $\mathrm{D} \times \mathrm{A} \times \mathrm{E}$ & & & 0.19 & 0.003 & 0.006 & 0.189 & 0.001 & 0.001 & 0.049 \\
\hline $\mathrm{D} \times \mathrm{A} \times \mathrm{E}_{1 \text { May vs. } 8 \text { May }}$ & & & 0.384 & 0.055 & 0.094 & 0.289 & 0.094 & 0.122 & 0.709 \\
\hline $\mathrm{D} \times \mathrm{A} \times \mathrm{E}(1$ May +8 May $)$ vs. $1 \& 8$ May & & & 0.339 & 0.022 & 0.008 & 0.743 & 0.017 & 0.002 & 0.064 \\
\hline
\end{tabular}

zBloom in 2001 rated on a scale of 1 to 7 , where $1=$ very light, $4=$ moderate, and $7=$ very heavy. Values are least squares means adjusted for the covariate, number of fruit harvested per tree in 2000. The covariate did not interact with any of the treatment variables.

yContrast tests the hypothesis that 1 May = 8 May for Accel treatment.

${ }^{x}$ Contrast tests the hypothesis that the average response of 1 May and 8 May $=$ the repeat treatment of 1 May plus 8 May for Accel treatment.

or Accel. A normal analysis of covariance was performed with a common slopes model and indicated that fruit weight was significantly lower for trees sprayed with ethephon than for trees not sprayed with ethephon (data not presented). Accel did not affect fruit weight.

2002. Fruit set was reduced by Accel, but not by ethephon (Table 6). Fruit harvested per tree, yield, crop density and yield efficiency were not related to ethephon concentration, but when ethephon was combined with Accel fruit set and yield increased with increasing ethephon concentration. Accel increased fruit weight and reduced the percentage of small fruit, but both response variables were not significantly influenced by ethephon. Crop value was linearly and positively related to ethephon concentration $(P$ $=0.057$ ). Bloom rating in 2003 was not significantly influenced by treatment. Analysis of covariance was used to determine if treatments influenced fruit weight. The three-way interaction term was not significant, so a normal analysis of covariance was performed with a common slopes model. Fruit weight was linearly related to fruit/tree, and fruit weight was not significantly related to ethephon concentration, but fruit weight was greatest for Accel-treated trees (Table 6).
Table 4. The effect of combining Accel and ethephon on fruit weight (g) in 2000. Analysis of covariance was used to estimate least squares means at three levels of crop load (fruit/tree).

\begin{tabular}{lclcc}
\hline $\begin{array}{l}\text { Ethephon } \\
\left(\mathrm{mg} \cdot \mathrm{L}^{-1}\right)\end{array}$ & $\begin{array}{c}\text { Accel } \\
\left(\mathrm{mg} \cdot \mathrm{L}^{-1}\right)\end{array}$ & \multicolumn{3}{c}{ Fruit/tree } \\
\cline { 3 - 5 } 0 & 0 & $184 \mathrm{ab}^{\mathrm{z}}$ & $1700 \mathrm{a}$ & $167 \mathrm{a}$ \\
0 & 500 & $174 \mathrm{a}$ & $175 \mathrm{a}$ & $175 \mathrm{a}$ \\
100 & 0 & $192 \mathrm{ab}$ & $184 \mathrm{a}$ & $176 \mathrm{a}$ \\
100 & 500 & $217 \mathrm{~b}$ & $188 \mathrm{a}$ & $158 \mathrm{a}$ \\
\hline
\end{tabular}

${ }^{\mathrm{z}}$ Separation of least squares means within columns by the probability of the difference, $5 \%$ level.

\section{Discussion}

FruIT SET. Ethephon in the present study was less effective than in a previous study with spur 'Delicious' where ethephon at 400 $\mathrm{mg} \cdot \mathrm{L}^{-1}$ reduced fruit set when applied over a range of average fruit diameters (4.0 to $24.3 \mathrm{~mm}$ ) (Marini, 1996). However, Jones et al. (1991) found that ethephon at $400 \mathrm{mg} \cdot \mathrm{L}^{-1}$ was most effective on 'Fuji' when applied $2 \mathrm{~d}$ before bloom and effectiveness declined as application date was delayed. In the present study ethephon was not an effective thinner at concentrations $<300 \mathrm{mg} \cdot \mathrm{L}^{-1}$ and 
the thinning response to ethephon for 'Delicious' in a previous study was also related to dose (Marini, 1996). Variable thinning responses with ethephon were also reported in a series of papers from Australia, where results from single-season studies were reported. Three-year-old 'Fuji' trees on MM.106 rootstock were adequately thinned with 100 to $200 \mathrm{mg} \cdot \mathrm{L}^{-1}$ ethephon applied at petal fall or at $14 \mathrm{~d}$ after bloom (Jones et al., 1989). However, 5-year-old trees were not thinned sufficiently at either full bloom or $14 \mathrm{~d}$ after full bloom with 100 to $200 \mathrm{mg} \cdot \mathrm{L}^{-1}$ of ethephon, and concentrations of 400 to $800 \mathrm{mg} \cdot \mathrm{L}^{-1}$ were required to obtain adequate thinning at full bloom (Jones et al., 1990). Ethephon at the rate of $400 \mathrm{mg} \cdot \mathrm{L}^{-1}$ thinned 6-year-old 'Fuji'/MM.106 trees more effectively when applied at full bloom than at $10 \mathrm{~d}$ after full bloom (Jones et al., 1991). 'Gala' and 'Jonagold' trees, treated at full bloom, were effectively thinned with 800 and $200 \mathrm{mg} \cdot \mathrm{L}^{-1}$, respectively (Jones et al., 1993).

Factors leading to inconsistent thinning with ethephon include cultivar, spray volume, timing, and temperature. In preliminary tests in Virginia, 'Golden Delicious', 'Jonagold', and 'Rome Beauty' were over-thinned by postbloom sprays of ethephon at concentrations $>300 \mathrm{mg} \cdot \mathrm{L}^{-1}$, but 'Gala' was not adequately thinned at the rate of $900 \mathrm{mg} \cdot \mathrm{L}^{-1}$ (unpublished data). Spur 'Delicious' trees

Table 5. Fruit set (fruit/100 blossom clusters), yield, average fruit weight (FW), crop density (CD), yield efficiency (YE), and return bloom in 2002 as influenced by spraying 'Campbell Redchief Delicious' trees with varying concentrations of Accel, with and without ethephon in 2001.

\begin{tabular}{|c|c|c|c|c|c|c|c|c|c|c|}
\hline $\begin{array}{l}\text { Ethephon } \\
\left(\mathrm{mg} \cdot \mathrm{L}^{-1}\right)\end{array}$ & $\begin{array}{c}\text { Accel } \\
\left(\mathrm{mg} \cdot \mathrm{L}^{-1}\right)\end{array}$ & $\begin{array}{c}\text { Fruit } \\
\text { set }\end{array}$ & $\begin{array}{c}\text { Fruit } \\
\text { harvested/ } \\
\text { tree }\end{array}$ & $\begin{array}{c}\text { Yield } \\
\text { (kg/tree) }\end{array}$ & $\begin{array}{c}\text { Fresh } \\
\text { wt } \\
(\mathrm{g})\end{array}$ & $\begin{array}{c}\mathrm{CD} \\
\text { (fruit } / \mathrm{cm}^{2} \text { ) }\end{array}$ & $\begin{array}{c}\mathrm{YE} \\
\left(\mathrm{kg} \cdot \mathrm{cm}^{-2}\right)\end{array}$ & $\begin{array}{c}\text { Fruit } \\
<56 \mathrm{~mm} \\
(\%)\end{array}$ & $\begin{array}{c}\text { Crop } \\
\text { value } \\
\text { (\$/tree) }\end{array}$ & $\begin{array}{l}\text { Bloom } \\
\text { ratingz }\end{array}$ \\
\hline \multirow[t]{5}{*}{0} & 0 & 64.8 & 974 & 163 & 167 & 7.6 & 1.28 & 12.3 & 105.66 & 3.4 \\
\hline & 50 & 43.8 & 837 & 143 & 172 & 6.9 & 1.18 & 11.7 & 95.16 & 3.9 \\
\hline & 100 & 58.9 & 930 & 149 & 162 & 5.6 & 0.90 & 18.6 & 91.40 & 3.2 \\
\hline & 150 & 55.9 & 871 & 141 & 163 & 6.4 & 1.02 & 17.9 & 88.15 & 2.9 \\
\hline & 200 & 72.3 & 1104 & 160 & 147 & 7.8 & 1.15 & 26.6 & 91.23 & 3.1 \\
\hline \multirow[t]{5}{*}{300} & 0 & 67.3 & 902 & 142 & 158 & 6.4 & 1.00 & 17.5 & 84.42 & 3.8 \\
\hline & 50 & 61.6 & 904 & 140 & 156 & 7.2 & 1.12 & 18.6 & 83.98 & 4.6 \\
\hline & 100 & 52.9 & 765 & 126 & 164 & 6.2 & 1.02 & 14.0 & 81.41 & 3.6 \\
\hline & 150 & 53.8 & 841 & 131 & 155 & 7.2 & 1.12 & 20.9 & 77.02 & 4.0 \\
\hline & 200 & 70.7 & 804 & 131 & 165 & 5.8 & 0.98 & 16.9 & 80.66 & 3.0 \\
\hline \multicolumn{11}{|c|}{$P$ value from contrasts $y$} \\
\hline Ethephon (E) & & 0.657 & 0.030 & 0.008 & 0.527 & 0.502 & 0.372 & 0.917 & 0.003 & 0.399 \\
\hline $\operatorname{Accel}(\mathrm{A})$ & & 0.077 & 0.421 & 0.413 & 0.644 & 0.396 & 0.325 & 0.135 & 0.383 & 0.649 \\
\hline $\mathrm{A}_{\mathrm{L}}$ & & 0.437 & 0.907 & 0.372 & 0.192 & 0.629 & 0.302 & 0.013 & 0.088 & 0.283 \\
\hline $\mathrm{A}_{\mathrm{Q}}$ & & 0.008 & 0.058 & 0.086 & 0.433 & 0.265 & 0.332 & 0.447 & 0.322 & 0.641 \\
\hline $\mathrm{E} \times \mathrm{Al}$ & & 0.563 & 0.117 & 0.649 & 0.062 & 0.135 & 0.194 & 0.053 & 0.891 & 0.964 \\
\hline $\mathrm{E} \times \mathrm{A}_{\mathrm{L}}$ & & 0.405 & 0.084 & 0.561 & 0.023 & 0.769 & 0.421 & 0.020 & 0.459 & 0.888 \\
\hline $\mathrm{E} \times \mathrm{A}_{\mathrm{Q}}$ & & 0.957 & 0.230 & 0.425 & 0.246 & 0.014 & 0.025 & 0.557 & 0.532 & 0.646 \\
\hline
\end{tabular}

${ }^{2}$ Least squares means from analysis of covariance.

$\mathrm{y} \mathrm{L}=$ the linear effect of Accel and $\mathrm{Q}=$ the quadratic effect of Accel.

Table 6. The effect of two levels of Accel combined with five levels of ethephon on fruit set, yield average fruit weight (FW), crop density (CD), yield efficiency (YE), crop value, and return bloom in 2003 when 'Mercier Redchief Delicious' trees were treated in 2002.

\begin{tabular}{|c|c|c|c|c|c|c|c|c|c|c|}
\hline $\begin{array}{l}\text { Accel } \\
\left(\mathrm{mg} \cdot \mathrm{L}^{-1}\right)\end{array}$ & $\begin{array}{l}\text { Ethephon } \\
\left(\mathrm{mg} \cdot \mathrm{L}^{-1}\right)\end{array}$ & $\begin{array}{l}\text { Fruit set } \\
\text { (fruit/100 } \\
\text { clusters) }\end{array}$ & $\begin{array}{c}\text { Yield } \\
\text { (kg/tree) }\end{array}$ & $\begin{array}{c}\text { Fruit } \\
\text { harvested/ } \\
\text { tree }\end{array}$ & $\begin{array}{c}\text { Fresh } \\
\text { wt } \\
(\mathrm{g})\end{array}$ & CD & YE & $\begin{array}{c}\text { Fruit } \\
<60 \mathrm{~mm} \\
(\%)\end{array}$ & $\begin{array}{c}\text { Crop } \\
\text { value } \\
\text { (\$/tree) }\end{array}$ & $\begin{array}{c}\text { Bloom } \\
\text { rating } \\
2003\end{array}$ \\
\hline \multirow[t]{5}{*}{0} & 0 & 81 & 112.4 & 1,070 & 106 & 6.4 & 0.68 & 79 & 23.2 & 1.0 \\
\hline & 150 & 76 & 115.4 & 935 & 122 & 6.2 & 0.76 & 55 & 43.3 & 1.5 \\
\hline & 300 & 76 & 108.2 & 986 & 117 & 5.5 & 0.60 & 55 & 32.6 & 2.0 \\
\hline & 450 & 91 & 103.1 & 865 & 121 & 5.7 & 0.69 & 50 & 36.0 & 3.3 \\
\hline & 600 & 85 & 78.5 & 643 & 127 & 3.9 & 0.48 & 43 & 28.6 & 1.3 \\
\hline \multirow[t]{5}{*}{125} & 0 & 71 & 90.8 & 492 & 185 & 2.8 & 0.52 & 10 & 19.2 & 1.7 \\
\hline & 150 & 57 & 80.2 & 637 & 133 & 5.6 & 0.70 & 44 & 25.4 & 2.3 \\
\hline & 300 & 50 & 71.6 & 447 & 171 & 4.1 & 0.64 & 20 & 19.5 & 2.3 \\
\hline & 450 & 55 & 89.5 & 609 & 147 & 4.5 & 0.66 & 23 & 38.2 & 1.5 \\
\hline & 600 & 74 & 122.3 & 861 & 149 & 5.6 & 0.81 & 28 & 46.7 & 4.0 \\
\hline \multicolumn{11}{|c|}{$P$ value from contrasts } \\
\hline Accel (A) & & 0.002 & 0.207 & 0.075 & 0.001 & 0.158 & 0.680 & 0.004 & 0.547 & 0.36 \\
\hline Ethephon (E) & & 0.409 & 0.933 & 0.916 & 0.757 & 0.790 & 0.693 & 0.812 & 0.175 & 0.65 \\
\hline $\mathrm{E}_{\mathrm{L}}$ & & 0.543 & 0.911 & 0.784 & 0.807 & 0.840 & 0.930 & 0.364 & 0.057 & 0.14 \\
\hline $\mathrm{E}_{\mathrm{Q}}$ & & 0.084 & 0.460 & 0.806 & 0.695 & 0.530 & 0.567 & 0.738 & 0.776 & 0.78 \\
\hline $\mathrm{A} \times \mathrm{E}$ & & 0.636 & 0.099 & 0.184 & 0.238 & 0.270 & 0.177 & 0.281 & 0.199 & 0.24 \\
\hline $\mathrm{A} \times \mathrm{E}_{\mathrm{L}}$ & & 0.659 & 0.043 & 0.049 & 0.187 & 0.067 & 0.034 & 0.203 & 0.082 & 0.75 \\
\hline $\mathrm{A} \times \mathrm{E}_{\mathrm{Q}}$ & & 0.196 & 0.053 & 0.318 & 0.495 & 0.918 & 0.508 & 0.451 & 0.099 & 0.16 \\
\hline
\end{tabular}

$\overline{\mathrm{z}} \mathrm{L}=$ the linear effect of ethephon and $\mathrm{Q}=$ the quadratic effect of ethephon. 
were adequately thinned or over-thinned at concentrations of 200 to $600 \mathrm{mg} \cdot \mathrm{L}^{-1}$, depending on timing (Marini, 1996). In general, the amount of thinning obtained with ethephon increased as spray volume increased (Bukovac, 1982; Jones et al., 1991). Spray volume should have been adequate in the present study because treatments were applied to drip with a hand-gun. Jones and Koen (1985) reported that thinning with ethephon was positively related to temperature. In the present study, temperatures on the day of application and for the following $3 \mathrm{~d}$ were $>21^{\circ} \mathrm{C}$ except for 2001 , when temperatures were 19 and $16{ }^{\circ} \mathrm{C}$ the day of and the day after treatment (Table 1); that year ethephon significantly reduced yield (Table 5). Byers et al. (1990) showed that chemical thinners may be more active during periods of low light, but solar radiation was relatively high for all experiments in the present study except for 2002, when yield per tree, number of fruit harvested per tree and crop density were not affected by treatment. Thinning spur 'Delicious' has been inconsistently affected by fruit size at the time of treatment. In one experiment ethephon applied with a hand-gun thinned individual limbs consistently over a wide range of fruit sizes ( 4.0 to $24.3 \mathrm{~mm}$ ), but in two experiments where whole trees were treated with an airblast sprayer, ethephon overthinned trees when applied when fruit diameter averaged $>18.0 \mathrm{~mm}$ (Marini, 1996; unpublished data). For 'Golden Delicious' sensitivity was greatest at 22 to $30 \mathrm{~mm}$, but fruitlets were not very responsive at 8 to $12 \mathrm{~mm}$ (Wertheim, 1997). These data seem to support Wertheim's (1997) suggestion that ethephon is most active when the natural tendency for apple fruitlet drop is high. At petal fall, higher rates are needed than at the start of the June-drop period.

There are few published reports on Accel to which results from the present study can be compared, but there are several reports for BA. In general, Accel is a less effective fruit thinner than BA (Clark et al., 1997) because when $\mathrm{GA}_{4+7}$ was added to BA thinning effectiveness was negatively related to $\mathrm{GA}_{4+7}$ concentration. The effect of Accel concentration on fruit set was inconsistent in the present study. In 1999,25 and $50 \mathrm{mg} \cdot \mathrm{L}^{-1}$ thinned inadequately, so higher concentrations were used in subsequent years. From 2000 to 2002 , Accel reduced crop density when applied at 100 to 125 $\mathrm{mg} \cdot \mathrm{L}^{-1}$. Accel was usually applied to small fruit in the present study, and thinning results may have been improved if treatments were applied when fruit diameter averaged 10 to $12 \mathrm{~mm}$. BA was most effective when applied at an average fruit diameter of $\approx 10$ $\mathrm{mm}$ (Greene, 1993), but in another study it was effective when applied over a period of $29 \mathrm{~d}$ after bloom (Elfving and Cline, 1993). Easy-to-thin cultivars required BA concentrations of 50 to $75 \mathrm{mg} \cdot \mathrm{L}^{-1}$, and difficult-to-thin cultivars required 75 to $100 \mathrm{mg} \cdot \mathrm{L}^{-1}$. BA also appeared most effective when applied at temperatures of at least $18{ }^{\circ} \mathrm{C}$ (Greene and Autio, 1994; 1995).

Applications of single materials usually do not adequately thin apples in the mid-Atlantic region of the United States (Byers, 1978), so combinations of two or more materials (Marini, 1997, 2002) or repeat applications are often used (Marini, 1996). When combined with carbamates, the thinning effectiveness of both Accel and ethephon was enhanced (Marini, 1997). However, there are no reports of combinations of Accel plus ethephon. In the present study the combination of the two materials provided more thinning than either material alone in only two of the four experiments. In 2000 crop density, but not fruit set per 100 blossom clusters, was reduced most by Accel at $100 \mathrm{mg} \cdot \mathrm{L}^{-1}$ plus ethephon at 500 $\mathrm{mg} \cdot \mathrm{L}^{-1}$. In 2002 fruit set was reduced by Accel at $125 \mathrm{mg} \cdot \mathrm{L}^{-1}$ and it was negatively related to ethephon concentration. When the materials were combined, crop density was positively related to ethephon concentration.
In 2000, when fruit diameter averaged 7.0 to $10.0 \mathrm{~mm}$, application of Accel or ethephon alone or in combination reduced fruit set and crop density. Although research data are limited, combinations of thinning chemicals and repeat treatments have not consistently provided more thinning than single applications of single materials. Naphthylacetamide plus low concentrations of ethephon are recommended on 'Elstar'(Weber, 1998). In Tasmania, a bloom spray of ethephon followed by a BA application at 140 to $160 \mathrm{mg} \cdot \mathrm{L}^{-1} 19$ to $23 \mathrm{~d}$ after full bloom (DAFB) was successful (Bound et al., 1993). Bound et al. (1997) reported that ethephon applied at $80 \mathrm{mg} \cdot \mathrm{L}^{-1}$ to 'Delicious' at full bloom (FB) did some thinning, but treatment at FB plus 7 DAFB was no better than a single application at full bloom. When ethephon at full bloom was followed by BA at 20 DAFB, thinning was better than with ethephon at full bloom and fruit set was negatively related to BA concentration in a curvilinear manner. Ethephon at full bloom plus ethephon + BA at 20 DAFB was not better than ethephon at full bloom plus BA at 20 DAFB. Byers (1978) reported that repeat carbaryl application to 'Starkrimson Delicious' at 10, 15, and 19 DAFB, thinned no better than a single application at 15 DAFB. Marini (1996) reported that repeat carbaryl application to 'Campbell Redchief Delicious' when fruit diameter averaged 4,9 , and $18 \mathrm{~mm}$ thinned no better than a single application made at any of those times. Repeat applications of NAA to 'Redchief Delicious' when fruit diameter averaged 4.2 and $7.1 \mathrm{~mm}$ was no more effective than a single application at the later date (Marini, 1996). Results from the present study support a previous report (Jones et al., 1997), where two applications of ethephon did not provide more thinning than a single application. Additional research is needed to determine if repeat applications are more effective than single applications of chemical thinners and to determine if a single treatment of a combination of two materials is more effective than single applications of each material applied at different times.

Fruit SIZE. Chemical thinners usually increase fruit size by reducing fruit numbers and thus the competition for metabolites among the remaining fruit on a tree (Buban and Lakatos, 1997; Marini, 1997). In the present study fruit weight was negatively related to crop load and was improved only when crop load was reduced. After adjusting for crop load, fruit weight was improved in 1 of 3 years by Accel and fruit weight was reduced by ethephon in 1 of 3 years. The effect of varying concentrations of BA on 'Empire' fruit weight was associated with changes in crop load (Elfving and Cline, 1993). Greene (1993) treated individual fruit in a cluster and found that BA increased fruit size, in part, by reducing competition, however it also increased fruit size directly, probably by stimulating cell division. Wismer et al. (1995) also reported that BA increased fruit weight independent of the thinning effect. BA applied to 'Delicious' and 'Golden Delicious' ( 50 and $100 \mathrm{mg} \cdot \mathrm{L}^{-1}$ ) at 11 to $12 \mathrm{~mm}$ fruit diameter reduced fruit set, and fruit weight and length/diameter ratio increased with concentration. The direct effect of Accel and ethephon on fruit weight appears to be inconsistent.

RETURN BLOOM. In the present study Accel did not improve return bloom, even when trees were adequately thinned. In other studies, when BA was used to thin apple trees, return bloom was usually improved compared to the nonthinned control (Elfving and Cline, 1993). Elfving and Cline (1993) found that Promalin, a combination of $\mathrm{BA}$ and $\mathrm{GA}_{4+7}$, was less effective for thinning than BA and did not promote return bloom. Gibberellins, especially $\mathrm{GA}_{7}$ inhibited flower bud formation in apple (Looney et al., 1985; McLaughlin and Greene, 1984), and the lack of return 
bloom following Accel treatment may be due to the inhibitory effects of $\mathrm{GA}_{7}$ on flowering. Byers (1993) combined $\mathrm{GA}_{4+7}$ with varying concentrations of ethephon. When combined with low, but not high rates of ethephon, $\mathrm{GA}_{4+7}$ counteracted ethephon's effect on thinning and return bloom. In the present study, ethephon improved return bloom in two of four experiments. Greene and Autio (1989) suggested that the time for maximum response for fruit thinning (10 $\mathrm{mm}$ average fruit diam) might be later than the time for maximum response for return bloom. In the present study Accel was usually applied when fruit diameter was less than10 $\mathrm{mm}$ but return bloom was not improved.

Crop value. Crop value has been reported for few thinning experiments. Results from the present study are similar to those previously published where crop value tended to be highest for treatments with excessive crops (Marini, 1997, 2002). The increased value of slightly larger fruit is not adequate to compensate for the reduced yield caused by treatments that thin adequately for return bloom. These results emphasize the fact that a major reason for fruit thinning is to improve return bloom and encourage annual cropping.

\section{Literature Cited}

Bound, S.A., K.M. Jones, and M.J. Oakford. 1997. Post-bloom thinning with 6- benzyladenine. Acta Hort. 463-499.

Bound, S.A., K.M. Jones, B. Graham, M.J. Oakford, and M.H. Tichon. 1993. Modelling the effects of timing and rates of application of benzyladenine as a secondary thinner of 'Fuji' apple after ethephon. J. Hort. Sci. 68:967-973.

Buban, T. and T. Lakatos. 1997. Benzyladenine for treating trees of hard to thin apple cultivars. Acta Hort. 463:509-515.

Bukovac, M.J. 1982. Low volume applications of plant growth substances to fruit trees. XXI. Intl. Hort. Congr. Hamburg 1:1062 (abstr.).

Byers, R.E. 1978. Chemical thinning of spur 'Golden Delicious' and 'Starkrimson Delicious' with sevin and vydate. HortScience 13: 59-61.

Byers, R.E. 1987. Tree-row-volume spraying rate calculator for apples. HortScience 22:506-507.

Byers, R.E. 1993. Controlling growth of bearing apple trees with ethephon. HortScience 28:1103-1105.

Byers, R.E., J.A. Barden, and D.H. Carbaugh. 1990. thinning of spur 'Delicious' apples by shade, terbacil, carbaryl, and ethephon. J. Amer. Soc. Hort. Sci. 115:9-13.

Clark, T.E., T.L. Robinson, A.N. Lakso, and W.C. Stiles. 1997. The effects of different ratios and concentrations of benzyladenine and $\mathrm{GA}_{4+7}$ on fruit size and yield of apple trees. HortScience 32:524 (abstr.).

Elfving, D.C. and R.A. Cline. 1993. Benzyladenine and other chemicals for thinning 'Empire' apple trees. J. Amer. Soc. Hort. Sci. 118:593-598.

Greene, D.W. 1993. A review of the use of benzyladenine (BA) as a chemical thinner for apples. Acta Hort. 329:231-236.

Greene, D.W. and W.R. Autio. 1989. Evaluation of benzyladenine as a chemical thinner on 'McIntosh' apples. J. Amer. Soc. Hort. Sci. 114: $68-73$.

Greene, D.W. and W.R. Autio. 1994. Combination sprays with benzyladenine to chemically thin spur-type 'delicious' apples. HortScience 29: 887-890.
Greene, D.W. and W.R. Autio. 1995. Evaluation of Accel as a chemical thinner and suggestions for use in 1995. Fruit Notes 1995(2)1-5.

Jones, K.M., S.A. Bound, P. Gillard, and J.J. oakford. 1997. A working model of apple thinning. Acta Hort. 463:475-480.

Jones, K.M. and B.G. Graham, S.A. Bound, and M.J. Oakford. 1993. Preliminary trials to examine the effects of ethephon as a thinner of 'Gala' and 'Jonagold' apple. J. Hort. Sci. 68:139-147.

Jones, K.M. and T.B. Koen. 1985. Temperature effects on ethephon thinning of apples. J. Hort. Sci. 60:21-24.

Jones, K.M., T.B. Koen, and M.J. Oakford. 1991. How volume of spray affects the thinning of red 'Delicious' with ethephon. N.Z. J. Crop Hort Sci. 19:31-36.

Jones, K.M., T.B. Koen, M.J. Oakford, and S.A. Bound. 1989. Thinning 'Red Fuji' apples with ethephon or NAA. J. Hort. Sci. 64:527-532.

Jones, K.M., T.B. Koen, M.J. Oakford, and S.A. Bound. 1990. Thinning 'Red Fuji' apples using ethephon at two timings. J. Hort. Sci. 381-384

Jones, K.M., T.B. Koen, and R.J. Meridith. 1983. Thinning Golden Delicious apples using ethephon sprays. J. Hort. Sci. 58:381-388.

Koen,T.B. and K.M. Jones. 1985. A model of ethephon thinning of Golden Delicious apples. J. Hort. Sci. 60:13-19.

Lenter, M. and T. Bishop. 1993. Experimental design and analysis. $2^{\text {nd }}$ ed. Valley book Co., Blacksburg, Va.

Looney, N.E., R.P. Pharis, and M. Noma. 1985. Promotion of flowering in apple trees with gibberellin $\mathrm{A}_{4}$ and $\mathrm{c}-3$ epi-gibberellin $\mathrm{A}_{4}$. Planta 165:292-294.

Marini, R.P. 1996. Chemically thinning spur 'Delicious' apples with carbaryl, NAA, and ethephon at various stages of fruit development. HortTechnology 6:241-246.

Marini, R.P. 1997. Oxamyl is an effective apple fruit thinner when used alone or when combined with other thinners. HortTechnology 7:253-258.

Marini, R.P. 2001a. Experience with thinning: what factors contribute to contradicting results? HortScience 37:484-486.

Marini, R.P. 2001b. Training and pruning apples trees. Va. Coop. Ext. Publ. 422-021.

Marini, R.P. 2002. Thinning 'Golden Delicious' and spur 'Delicious' with combinations of carbamates and NAA. HortScience 37:534-538.

Marini, R.P. 2003. Approaches to analyzing experiments with factorial arrangements of treatments plus other treatments. HortScience 38: $117-120$

Marini, R.P., J.A. Barden, J.A. Cline, R.L. Perry, and T. Robinson. 2002. Effect of apple rootstocks on average 'Gala' fruit weight at four locations after adjusting for crop load. J. Amer. Soc. Hort. Sci. 127:749-753.

McLaughlin, J.M. and D.W. Greene. 1984. Effects of BA, GA ${ }_{4+7}$, and daminazide on fruit set, fruit quality, vegetative growth, flower initiation, and flower quality of 'Golden Delicious' apple. J. Amer. Soc. Hort. Sci. 109:34-39.

SAS Institute Inc. 1992. SAS/STAT user's guide, version 6, $4^{\text {th }}$ ed. SAS Institute, Cary, N.C.

Weber, H.J. 1998. Fruit thinning of cv. Elstar. Acta Hort. 466:143148.

Werthein, S.J. 1997. Chemical thinning of deciduous fruit trees. Act Hort. 463:445-462.

Wismer, P.T., J.T.A. Proctor, and D.C. Elfving. 1995. Benzyladenine affects cell division and cell size during apple fruit thinning. J. Amer. Soc. Hort. Sci. 120:802-807. 